\title{
Financial indicators of the sustainability of pastoral farms and their relationship with environmental sustainability
}

\author{
NICOLA M. SHADBOLT, STUART D. MORRISS and TERRY C. KELLY \\ Department of Agribusiness and Resource Management, Massey University, Palmerston North
}

\begin{abstract}
Agri-environmental indicators developed in New Zealand to date have focused more on environmental and biophysical indicators than on social and financial measures. However, the latter are increasingly seen as pre-requisites to achieving long-term financial and social viability in agriculture. At present environmental costs are internalised in the financial performance of farm businesses because environmental protection in agriculture is funded almost entirely by farmers. This paper presents a preliminary examination of the perceptions of farmers on the relationship between farm financial resources and the environmental effects of farming. It aims to identify pragmatic and reliable financial indicators of sustainable agriculture at both the farm and the regional or national level. The paper will introduce a range of indicators used to measure the financial health of a business and will evaluate them for their ability to measure the economic sustainability of farm businesses over time. Farmer perceptions of the existence of links between the financial and environmental indicators will be explored through analysis of interview responses.
\end{abstract}

Keywords: financial health, sustainability indicators, environmental indicators, financial indicators

\section{Introduction}

Sustainable farming by definition is long term. Thus, any study examining indicators of farm business sustainability must take the longer-term view into account. Many of the traditional indicators of farm business profitability are measures of historical or reasonably foreseeable future outcomes. Generally, they focus on the efficiency of the business, its ability to optimise returns from inputs, and its liquidity and debt structure. Combined, these measures indicate the business's ability to meet its current commitments. Some studies have suggested that these indicators can also be used to measure the sustainability of a business, but have concluded that it is difficult to relate them to social and environmental indicators of sustainability (OECD 1996). If financial indicators can measure the ability of the business to maintain itself over time, that is, the long-term financial health of the business is not jeopardised by current practices, then they should also be consistent with the indicators adopted to measure social and environmental sustainability.

Financial performance indicators are some of the factors that influence the decisions and behaviour of farmers. In other words they are driving forces influencing the "responses" farmers will make. The question is how they affect the responses. In this research project, we aim to obtain a better understanding of how financial performance indicators influence farmers' decisions, farm management practices (the behavioural response), and the farming environment.

Business analysis will not explain these responses. The effects of the financial driving forces can be predicted only with a better understanding of the range of factors that influence farmers decisions and management behaviour, and the place of financial driving forces within them. Fundamental to this research is the idea that people, through their decisions and actions, will in large part determine the future fate of our natural resources.

Economics and sustainable land management practices

The indicators used to evaluate farm financial performance in any one year are different from those used to assess the financial health of a business. Excellent farm financial performance may well be indicated in the short term even though financial health of the business is not being maintained. Long-term financial performance requires maintenance or enhancement of both the financial and the biophysical resources of the business often at a short-term cost.

Culver \& Seecharan (1986) identified that farmers with planning horizons long enough to benefit from conservation practices, were more likely to adopt such practices. Perhaps for this reason, age and tenure were also found to be significant to adoption for financial reasons. For example, younger farmers appear to perceive erosion as a greater problem, and hence conservation practices to be more worthwhile, than older farmers. They are more likely to accept the financial 
risk associated with implementing conservation practices than older farmers. Adoption of conservation technologies by farmers was also identified by Culver \& Seecharan (1986) to be highly dependent on the availability, type and form of technical and economic information.

The essential requirement for short-term viability, particularly among farmers with low net incomes, conflicts with carrying out more conservation if this might jeopardise their short-term level of income and business viability. In this respect Rauniyar \& Parker (1996) found, in a national survey of pastoral farmers, the imperative from the farmers' point of view that changes in the management of physical resources to achieve sustainability, be profitable. In a study to quantify Bedfordshire farmers' attitudes to conservation, Beedell \& Rehman (1996) found that even when farmers believed they could do more in terms of farm conservation, they felt too constrained by economic considerations to do so. Specifically, debt, or the inability to borrow additional funds, is cited as an important determinant of a farmer's ability to adopt conservation practices. Supalla et al. (1995) concluded that the socioeconomic factors which influenced behaviour of farmers with respect to nitrogen fertiliser management in Nebraska were education, experience, farm size, and the financial health of the farm.

Minimising risk was found to be a major consideration in the broadleaf crop rotation practices New South Wales farmers adopt and the number one issue in this respect was farm profitability (Lockie et al. 1995). Farmers stated that the farm as an economic unit could not be divorced from its biophysical sustainability as a production, or ecological, unit.

While it is recognised that a number of factors influence farm business decision-making and that resolving conflicting goals is the key to successful operations, particularly for family businesses, it is proposed that some businesses will struggle to achieve the goal of sustainability. McGregor et al. (1996) found that Scottish farmers rank the maintenance of their land resource, the environment and their way of life ahead of the traditionally accepted objectives of profit maximisation and risk minimisation. Nevertheless, the research reviewed suggests that economic and other constraints play an important role in whether successful farmers can achieve the objectives for biophysical sustainability.

\section{Financial indicators}

The three drivers that affect farm business financial performance, as measured by return on investment equity, are: operating profit margins, capital turnover and leverage (Boehlje 1994). Specific decisions on cost control, efficiency and productivity affect each of these drivers. The eight areas outlined by Boehlje (1994) which provide a comprehensive overview of the performance of the farm business are:

\section{Risk bearing ability (solvency) \\ Total assets \\ Total liabilities \\ Owner's equity \\ Debt to asset ratio \\ Profitability \\ Gross Farm Income \\ Total expenses \\ Net income \\ Return on Equity}

\section{Capital efficiency}

Asset turnover ratio

Debt servicing capacity

Current ratio

Debt to income ratio

\section{Savings behaviour \\ Reinvestment rate}

\section{Labour efficiency}

Revenue per employee

\section{Revenue generation and cost control}

Economic Farm Surplus Operating Profit Margin

\section{Cost composition \\ Fixed cost percentage}

These eight areas are similar to those identified by an American Farm Financial Standards Task Force (Barnard 1991) in that they include measures for profitability, solvency, efficiency, and the repayment capacity of the farm business, but they also add measures for reinvestment rates and cost containment. These two additions indicate both a growth focus for the business and the degree to which its commitments could affect the business.

Another recognised method of assessing the financial performance or, more specifically, the financial health of the business is the value added approach (Taylor 1994). This is based on the concept that value can be created only when operating profits exceed the cost of all of the capital employed to produce those earnings. It is a residual income measurement which subtracts the cost of capital from net operating profits after tax generated in the business.

The ownership of most assets is financed by a mix of debt and equity. The appropriate cost of funds is therefore one that considers the claims of each group in proportion to its targeted relative capital contribution (Rappaport 1986).

A business able to increase its assets after having paid the costs of both equity and debt, is adding value for its shareholders. Where equity and debt commitments are met but at the expense of the business, the value of the business, as a reflection of its future earning worth, declines. The objective of optimising the net present value of the business, suggested by Kerr (1997) as the raison d'etre of all businesses, requires current spending 
and investments by the business to be focused on achieving a balance between present returns and future earning ability.

The concept of adding value to the business lends itself to the concept of sustainability, as it is possible to extend the definition of capital resources to include the land itself and its ability to produce now and in the future. Consequently, the value of a cash flow stream that produces positive results at the expense of resource depletion, can be compared with one which maintains the resource even if it reduces short term profit.

The goal of sustainable land management should be to at least achieve an equilibrium between cost of capital and net operating profits after tax, without the necessity of further capital inputs (Taylor 1994). Either, or both, net operating profit after tax and cost of capital can be adjusted to achieve this equilibrium. The ability to adjust, particularly in family farm businesses, provides a robustness that is not always possible in corporate structures (Pomeroy 1992; Hebling 1996).

The value-based approach is based on the assumption that the productive capacity of the business is being maintained. For a farming business this must include not only the replacement of plant, machinery, buildings, tracks, drains and fences but also the maintenance (or replenishing) of soil fertility (Taylor 1994).

However, as identified by Saunders \& Cumberworth (1993), business performance indicators that describe the status of system sustainability will undoubtedly lag behind ecological indicators of performance owing to the buffering capacities of biological systems. This would certainly be the case if only indicators such as profitability, efficiency and solvency were used. In other words, the impact of a practice such as inadequate fertiliser application or soil compaction may not be reflected in the profitability or viability of the business until a number of years after the event. The SCARM Expert Committee (CSIRO 1993) recommended the change in long-term real net farm output over a 5- to 10 -year period as a financial indicator because it captures the effects of management practices over time. However, such retrospective wisdom is not always useful as a management or policy tool if the business or country has a sustainability goal. It is important instead to have indicators that value and/or measure factors known to affect future productivity and for these to be reflected in the current economic performance indicators of the business.

Maintaining the productivity of the resource base is only one factor in achieving long-term farm business financial viability. To date, however, it is the one factor not included when assessing the financial performance of a farm business. It is critical to the overall health of the business, especially its long-term productivity.
Some of the financial indicators proposed in this paper include:

Bio-Eco Value Created calculated as the Net Operating Profit after Tax (NOPAT) adjusted for asset maintenance less Cost of Capital

Net Present Cost of continuing asset maintenance trends

Net Present Value of continuing productivity trends.

The first indicator enables an assessment to be made of whether value, both economic and biophysical, is being created or lost, owing to the current methods of land management. The cost or benefit of continuing current trends in both asset maintenance and productivity are assessed in the last two indicators to give a measure of the effect on the business of persisting with its a current practices.

A spreadsheet model has been developed that calculates those indicators that are more relevant to this longer-term focus. The model uses both physical output and input data and conventional financial data to generate a range of indicators for an individual farm. The model has been applied to a data set of five consecutive years of 200 individual sheep and beef cattle farm physical and financial reports. Further analysis will identify which indicators are the most applicable and useful to management within a sustainability framework, that is, which indicators provide the best indication of the balance between current viability and future productivity.

\section{Field work observations to date}

Farmers make the day-to-day and longer-term management decisions that determine how their farming affects the environment. Understanding their perceptions of what factors influence their management decisions and actions is critical, particularly for policy-makers. Research has identified a range of such factors. Within this context, financial factors are but one of the set influencing farmers' management decisions and actions.

In the field work, semi-structured interviews were carried out with 20 dairy and 20 sheep and beef farmers. Issues covered include:

- farmers' views about what a sustainable farming operation is;

- how different financial scenarios influence their management decisions, both short and long term;

- their goals and where sustainability issues fit within them;

- how farmers "value" their land; and

- the key environmental issues of relevance to their properties and the management practices that affect them. 
Farmers were asked to describe how they would characterise a sustainable sheep and beef farm. Responses consistently referred to sustainable farming in productivity and profitability terms. Underlying resource sustainability was considered necessary, but not sufficient, for sustainable farming systems. Maintenance of soil quality of was often noted as being vital, primarily in terms of their productive capacity, which for the farmers interviewed, included maintaining the soil's stability, i.e., avoiding erosion. In some cases the prior question of the sustainability of the land use was considered in the discussion. However, for the most part, the farmers adopted a realistic position, namely that the farms existed, and therefore, what would constitute a sustainable farming system. One concept identified was that productivity had to be repeatable. For example, comments made in the interviews included:

"To me sustainability is repeatability.

"I'm talking repeatability in stock performance, numbers and productivity terms. But they're influenced directly by loss of topsoil."

While repeatable productivity is important, the level of productive performance was less important. For example, from one farmer:

"A lot of people are performing at a lower level, that's fine. But a lot of people are performing at low levels and I call them miners, not farmers. They are mining the resource because they're not putting on fertiliser. It's not sustainable, it's not repeatable year in-year out."

"I think with the current levels of fertiliser yes, definitely, the farm is sustainable at present levels."

“... there is a limited amount of land, ... the value of the land is never going to reflect what you can get off it. It is always going to be worth more than what you can actually produce off the land, because it is a scarce resource."

The farmers generally agreed that to be sustainable, the resources of the farm had to be maintained. However, they didn't accept that this meant that no soil erosion was allowable. In some cases they separated the resources from which the productivity of the farm was generated, and those on which the farm sat.

"Inputs have to match outputs. With inputs I mean not just plugging in fertiliser - I mean the resources that are currently sitting on the deck which is only the top two inches. When you go and buy some (land) you only buy the top couple of inches. All the rest is only there to hold the top two inches up."

"Inputs in the way of what you're putting into the property through fertiliser, erosion control and everything else is greater than the output so that the actual property is more than holding it's own - it's improving."

"There's got to be a lot of input. A lot of farmers think you can just send the sheep off, the wool off and the cattle off, but you've got to put something back into it. They're not going to grow from nothing."

All farmers interviewed to date agreed that to be sustainable, farming operations had to be financially sustainable. This included their being well managed and efficiently farmed, and able to meet debt servicing requirements and to adapt and react to changes in a timely way. For example:

"Every business must make a profit. You can't just be there for the lifestyle or anything else. There's got to be money in it. Even if it's just annually reducing your debt, or being able to maintain or improve the fencing."

"You have got to be adaptable. At the moment you know, you have got to be prepared to re evaluate all the time. Re-evaluate, and not just re evaluate but act on it. On what you find."

“... when you had more money you would certainly be looking after your land because in the good years you've got to put it back to get you through the bad years."

"It's a (sustainable) property where the productivity is at least maintaining over time, or preferably improving. Certainly not declining over time. If fertility is dropping over time or soil erosion is not being controlled, I guess that's not going to be sustainable. As far as sustainable management practices [is concerned] any management practice which is not sustainable is probably not profitable so you'd probably do something about that."

"I've certainly got no ambition to get everything out of this farm and leave it in a state for the next generation that is un-farmable. In fact I hope to 
leave it in a better state ... When it comes down to it, on the farming side, it's a business. Any sustainable business, it's got to be profitable."

And even where trees have been planted for erosion control reasons, the integration of them into the farming operation is not simple. For example:

"Your livestock operation is the engine for your whole operation - providing the income for the rest. So if you're starting to neglect that, the whole job's starting to get a bit sick."

Primarily on-site issues were included by farmers interviewed. Few expressed undue concern about the off-site biophysical effects of their farming operation. However, a number of them did express concern about the community effects. For example:

"There's so many farms that have been bought up for forestry within this area that it's really quite scary to think are we going to have our school in five years' time, or what's the community going to be like?"

... People are not making a living in their own communities."

"It's amazing how much good farming neighbours help." ... It's really good, that little bit of quiet competition when you can egg each other on and it's good and you can help each other."

"We cling to the neighbours we've got and are rather resentful of these other ones. These lifestyle blocks are turning over - it sort of changes attitudes to neighbours. We've hardly clapped eyes on the people that are in there now."

"I've got one farming neighbour. No longer do you get - not that you want reps calling at your door every day - but there's absolutely no point in them coming here any more - there's no farming. You don't get the Meat Board or the Wool Board having their woolshed meetings here any more."

\section{Conclusion and further research}

Further analysis is required to identify which physical and financial indicators are the most applicable and useful to management within a sustainability framework.

Observations from the farmer interviews to date indicate that sustainability is important to the farmers interviewed, and generally they felt that their farms could be farmed sustainably. This didn't mean that they all felt they were. A number of farmers recognised that there were issues that still needed to be addressed. The difference between whether the farms were sustainable or not was not land use dependent, but dependent on how the land was managed. For them, financial factors are critical, both to their understanding of the concept of sustainability of their farming operations, and in terms of the factors influencing their ability to attain that goal.

\section{REFERENCES}

Barnard, F.L. 1991. Farm financial standards: An overview of the recommended guidelines. Agrifinance, September 1991: 16-17.

Beedell, J.D.C.; Rehman, T. 1996. A meeting of minds for farmers and conservationists? Some initial evidence on attitudes towards conservation from Bedfordshire. Farm management 9 (6): 305-313

Boehlje, M. 1994. Evaluating farm financial performance. Journal of the American Society of Farm Managers \& Rural Appraisers 58 (1): 109-115.

Culver, D.; Seecharan, R. 1986. Factors that influence the adoption of soil conservation technologies. Canadian farm economics 20: 2, 9-13

CSIRO, 1993. Sustainable agriculture. Tracking the indicators for Australia and New Zealand. Standing Committee on Agriculture \& Resource Management CSIRO Report No. 51.

Hebling, R. 1996. Survival of family farms. Family farming without state intervention. New Zealand rural business 2:summer/autumn :36-39.

Kerr, R. 1997. Whither cooperative dairy companies? New Zealand Business Roundtable.

Lockie S.; Mead A; Vanclay F; Butler B. 1995. Factors encouraging the adoption of more sustainable crop rotations in South-East Australia: Profit, sustainability, risk and stability. Journal of sustainable agriculture 6 (1): 61-79.

McGregor, M; Willock, J; Dent, B; Deary I; Sutherland, A; Gibson, G; Morgan, O; Grieve, B. 1996. Links between psychological factors and farmer decision making, Farm management 9 (5), Spring.

OECD, 1996. Switzerland: Progress report on farm financial resources indicators. EPOC/RD (96) 157.

Pomeroy, A. 1992. Rural New Zealand - structures \& issues. Proceedings of Joint Conference NZ Geographical Society and the Institute of Australian Geographers, Jan. 1992.

Rappaport, A. 1986. Creating shareholder value. New York: The Free Press. pp. 50-51.

Rauniyar, G; Parker, W. 1996. Constraints to farm level adoption of new sustainable technologies and 
management practices in New Zealand pastoral agriculture. Research report to MAF Policy, Wellington

Saunders, L; Cumberworth, S 1993. Farm business sustainability. Understanding viability trends overtime. MAF Policy Technical Paper 92/19.

Supalla, R.J; Selly, R.A: Bredeweg, S; Watts, D 1995. Adoption of nitrogen and water management practices to improve water quality. Journal of soil and water conservation 50(1): 77-82.

Taylor, R.N. 1994. Capital maintenance: Enhancing value over the long-term. Proceedings of the 1994 NZ Conference on Sustainable Land Managment: 128-131. 